\title{
NON-COERCION BEYOND VIRTUAL ENVIRONMENTS: CAN STUDYING BE PLEASANT?
}

\author{
Rosângela Darwich ${ }^{1}$, Ana Letícia Nunes ${ }^{2}$, \& Agnnes de Souza ${ }^{3}$ \\ ${ }^{1}$ Graduate Program in Communication, Languages and Culture; Center for Health and Biological \\ Sciences, Universidade da Amazônia (Brazil) \\ ${ }^{2}$ Center for Health and Biological Sciences, Universidade da Amazônia (Brazil) \\ ${ }^{3}$ Graduate Program in Communication, Languages and Culture, Universidade da Amazônia (Brazil)
}

\begin{abstract}
In Brazil, school dropout exceeded the limits of public schools and can no longer be understood as an unfolding of social factors. One of the explanatory hypotheses for this fact relates boredom, lack of concentration and learning difficulties in the classroom to the constant experiences of children and teenagers in virtual environments. An alternative solution consists of using new technologies at school. However, it is likely that methodological changes are counterproductive if the disciplinary bases of the school system are maintained, as the negative effects of coercion are incompatible with the freedom experienced virtually. This study aims to present relationships between non-coercion and staying in school. For this purpose, it presents the theoretical assumption that underlies an action research implemented at the University of Amazônia, in Belém: spontaneous and pleasurable engagement in activities and recognition of personal and social value are positive effects of non-coercive interactions. Therefore, we investigate whether the formation of small groups with non-coercive characteristics in schools favors among students the development of a pleasurable engagement in academic activities. University students present literary texts to groups of about fifteen students, opening space on a weekly basis for shared reading, reflections and dialogue with the absence of performance evaluations. We have obtained positive results in areas such as assertiveness, empathy, resilience, creativity, autonomy and pleasure in reading, which unfolds in pleasure in studying. We expect that historically naturalized coercion in schools is brought to the center of attention, so that learning can be dissociated from fear and avoidance.
\end{abstract}

Keywords: School dropout, non-coercion, new technologies, literature.

\section{Introduction}

In Brazil, the education field reflects the huge differences between socioeconomic classes. Guzzo and Euzébios Filho (2005) summarize the situation: "the educational system, which results from a historical process, is configured in the midst of social and production relations that divided and still divide society into distinct economic groups and, even more, establishes a relationship between antagonistic social classes" (p. 40).

Sibilia (2012) draws attention to "the transmutation of the school into a company that sells services, with the concomitant chasm that opened up between public and private establishments [...] [so that those] sink into an irrecoverable mediocrity" (p 152). We have poor children in public schools and outside them, who are exposed to the dangers of the streets (Cardoso, Fernandes, Bastos, \& Sousa, 2015). Silva Filho and Araújo (2017) consider that the following factors are decisive for school dropout: "drugs, time at school, successive failures, lack of encouragement from family and school, need to work, excessive school content, alcoholism, location of school, vandalism, lack of formation of values and preparation for the world of work "(p. 36).

In a school characterized as a disciplinary institution based on a mix of continuous hierarchical surveillance and normalizing sanctions, low grades are just clear and punctual examples of other daily difficulties, such as sitting for several hours while trying to assimilate contents that are far from the known reality. What was unexpected is that school dropout started to affect children of the dominant classes, whose media subjectivities would bring with them boredom, demotivation and loss of focus in 
classes, justifying the most varied diagnoses of mental disorder. In such cases, disinterest is identified as the main reason for dropping out of school (Sibilia, 2012).

Faced with the possibility that the characteristics of students familiarized with technology since early age are incompatible with the traditional school, alternatives have been devised to ensure that children (we can assume, from the dominant classes) remain studying. This is the case with proposals for the use of new technologies in classrooms, which Veiga-Neto (2003) ironically identifies as "the good old modern school" (p. 123). Sibilia (2012) indicates that we do not yet have concrete solutions for the current crisis, and it is necessary to reinvent the school - "against boredom and dispersion, it is necessary to add density to the experience, arousing enthusiasm and the will to learn" (p. 210).

In order to understand how the new spaces that could solve the generalized problems that afflict the school would be, we distinguish, like Sidman (1989), coercive from non-coercive interactions. Therefore, we aim to present relations between non-coercion and permanence in school.

\section{Experiential groups: Non-coercion and pleasure in studying?}

Imposition and obedience through the threat of punishment characterizes coercive relationships (Sidman, 1989). If we consider the school, the student is provided with content to be learned and the possibility of advancing over school years if the necessary grades are reached and the number of absences does not exceed a certain limit. These general rules are accompanied by requests to keep silence and attention to the teacher in class. In this way, the traditional school is a perfect example of coercion. As the emotional effects generated by coercion are negative, it is expected that many will students try to distance themselves from study-related activities.

Non-coercion is as difficult to explain as the word freedom, perhaps because they are in fact close. We say that we like something when we reach for it spontaneously and whenever possible. Using school as an example of non-coercion is challenging, but Coy Mathis, an American elementary school student, has succeeded, stating: "I want to go to school. We play at break" (Favilli and Cavallo, 2016, p. 45).

Public schools are twice as coercive because students display skills that have no value among what is assessed and that, sometimes, even get in the way of what needs to be learned. That is why it is said that education is a form of exclusion and perpetuation of social disparities in which a large part of the population is. Thus, as for social exclusion, "the educational system figures as the main actor" (Guzzo \& Euzébios Filho, 2005, p. 43).

Faced with such a scenario, this study derives from an action research, conducted with a qualitative approach, that has been implemented by the Universidade da Amazônia (UNAMA), in Belém, in northern Brazil, since 2016. In its second phase (2020 to 2022) it is entitled "Poetry in Daily Life: Experiential Groups and Resilience". The ten meetings from each group are coordinated by undergraduate and graduate students and take place weekly at schools, NGOs and the UNAMA's clinic-school of Psychology (CLIPSI) and bring together about fifteen participants.

Experiential method, as described by Del Prette and Del Prette (2017), supports the group dynamics that aim to promote social skills and resilience through dialogue, shared reflections, drawings and paintings. In addition, the use of literary texts aims to provide an opportunity for the development of pleasure in reading, increasing the likelihood of studying also become a pleasurable act. It is expected that the construction of non-coercive interpersonal relationships allows one's realization of their social and individual importance, which contributes to joyous partaking in academic activities (Darwich \& Garcia, 2019).

Comparing pre-test and post-test measures, participants' reports and observations made during the meetings, we have obtained positive results in areas such as assertiveness and empathy, important for the prevention and overcoming of problems, as well as resilience, verified in the face of difficulties in the group and outside it. Creativity, autonomy and pleasure in reading observed in the groups are, through interviews with parents and teachers, also verified in the classroom and in the effort to carry out homework. We found that the pleasure of reflecting and exchanging ideas in groups is also measured by the participants' excellent attendance in the meetings. The school environment turns into a space that welcomes diversity and multiplicity, in which changes can happen. Instead of fear and avoidance of low grades and failures, they find pleasure in small advances, because social support is expected to protect and reading is to free. 


\section{Conclusions}

Pará is a state in northern Brazil, far away from the most developed centers. Since it's the second largest state in the country, there are huge internal distances. River paths, crossing the Amazon rainforest, for instance, are challenging routes between home and school (Almeida, 2010; Ruiz \& Domingues, 2008). Considering social inequality issues that prevail in this scenario, the inhabitants of the interior of Pará look for better living conditions in the capital, where they end up finding always new problems and, unfortunately, few solutions (Cardoso et al, 2015).

According to Sibilia (2012), "many current opinions, including the most official ones, seem to agree in one point: to $21^{\text {st }}$ century students, you need to offer fun" (p. 81). In this regard we can say that the less coercive the learning situation is, the funnier it will naturally be, and the closer to the student's reality, the more significant (Sidman, 1989). What resilient people have received in childhood is also very helpful: trust and support (Fischer \& Fröhlich-Gildhoff, 2019). Nor can we forget Paulo Freire, who imagined a school where "learning to read, writing, literacy is, first of all, learning to read the world, understanding its context not in mechanical manipulation of words, but in a dynamic relationship that links language and reality" (Freire, 2006, p. 8). That is the kind of education that truly stimulates students to seek knowledge and dialogue.

The central question presented in this work - can studying be pleasant? - is broad and complex, but reflection regarding its answer is necessary. The human being repeats sounds tirelessly to be able to communicate; crawls on the floor, falls and gets up as many times as necessary to walk; asks questions, invents answers; enters school and becomes more and more persistent, curious, critical, sensitive to the others, inventor of new possibilities. Part of the previous sentence is already true and the implementation of the other part depends on each one of us.

\section{References}

Almeida, R. (2010). Amazônia, Pará e o mundo das águas do Baixo Tocantins. Estudos Avançados, 24 (68), 291-298.

Cardoso, A., Fernandes, D., Bastos, A., \& Sousa, C. (2015). Metrópole Belém e sua centralidade na Amazônia Oriental Brasileira. EURE, Santiago, 41 (124), 201-223.

Darwich, R. A., \& Garcia, M. L. G. (2019). Grupos vivenciais e permanência com sucesso na escola: conquista de direitos. Revista Katálysis, 22 (3), 558-565.

Del Prette, Z. A. P., \& Del Prette, A. (Eds.) (2017). Habilidades sociais e competência social para uma vida melhor. São Carlos: EDUFSCar.

Favilli, E., \& Cavallo, F. (Eds.). (2016). Histórias de ninar para garotas rebeldes: Cem fábulas sobre mulheres extraordinárias. São Paulo: V\&R.

Fischer, S., \& Fröhlich-Gildhoff, K. Chancen-gleich. Kulturelle Vielfalt als Ressource in frühkindlichen Bildungsprozessen. Manual zur Qualifizierung pädagogischer Fachkräfte. Stuttgart, Germany: Kohlhammer, 2019.

Freire, P. (2006). A importância do ato de ler: em três artigos que se completam. (47 ${ }^{\text {th }}$ ed). São Paulo: Cortez.

Guzzo, R. S. L., \& Euzébios Filho, A. (2005). Desigualdade social e sistema educacional brasileiro: a urgência da educação emancipadora. Escritos sobre Educação, 4 (2), 39-48. Retrieved, March, 2, 2020, from: http://pepsic.bvsalud.org/scielo.php?script=sci_arttext\&pid=S167798432005000200005

Ruiz, R. M., \& Domingues, E. P. (2008). Aglomerações econômicas no sul-sudeste e no nordeste brasileiro: estruturas, escalas e diferenciais. Estudos Econômicos, 38 (4), 701-746. Retrieved, Februar, 5, 2020, from: http://www.scielo.br/pdf/ee/v38n4/v38n04a02.pdf

Sibilia, P. (2012). Redes ou Paredes: A escola em tempos de dispersão. Rio de Janeiro: Contraponto.

Sidman, M. (1989). Coercion and its fallout. Massachusetts: Authors Cooperative.

Silva Filho, R. B., \& Araújo, R. M. L. (2017). Evasão e abandono escolar na educação básica no Brasil: fatores, causas e possíveis consequências. Educação por Escrito, 8 (1), 35-48. Retrieved, March, 2, 2020, from: http://revistaseletronicas.pucrs.br/ojs/index.php/porescrito/article/view/24527/15729

Veiga-Neto, A. (2003). Pensar a escola como uma instituição que pelo menos garanta a manutenção das conquistas fundamentais da modernidade. In M. V. Costa (Ed.), A escola tem futuro? (103-126). Rio de Janeiro: DP\&A. 